\title{
Effect of Fly Ash Deposition on Biochemical Parameters of Different Crop Plants around Parichcha Thermal Power Plant, Jhansi, India
}

\author{
Sudarshana Sharma ${ }^{1}$, Vinit Kumar ${ }^{1}$, Krishna Kumar Yadav ${ }^{1 *}$, \\ Neha Gupta ${ }^{1}$ and Sanjay Kumar Vishwakarma ${ }^{2}$ \\ ${ }^{1}$ Institute of Environment and Development Studies, Bundelkhand University, \\ Jhansi, U.P., India \\ ${ }^{2}$ Department of Biotechnology, VBS Purvanchal University \\ Jaunpur-222003, U.P., India \\ *Corresponding author
}

\section{A B S T R A C T}

Keywords

Biochemical parameters fly ash, plant, soil, thermal power plant.

Article Info

Accepted:

28 July 2016

Available Online:

10 August 2016
The present study evaluated the effects of fly ash on biochemical parameters of wheat, maize, gram and pea nearby Parichha Thermal Power Plant, Jhansi. It was observed that increase in fly ash concentration to a limited extent increase the soil quality and plant growth. Adverse effects can be observed at high concentration of fly ash. The study revealed that the limited concentration of fly ash could be beneficial for agriculture. Use of fly ash in agriculture as nutrient can be economical and eco-friendly solution of its disposal.

\section{Introduction}

Fly ash is generally the by-product produced due to the combustion process. It is actually captured from the chimneys of coal fired power plants. Generally it is known to be rich in variety of trace elements like As, B, $\mathrm{Ca}, \mathrm{Mo}, \mathrm{S}, \mathrm{Sr}$, Se etc., but toxic when present in excess amount (Mehra et al., 2000). The crop productivity of the soil increases on the addition of significant amount of fly ash due to the presence of micronutrient and macronutrient in it. Crop productivity may also reduce if the concentration of toxic metal is high in the fly ash (Sharma et al., 2015; Murugan and Vijayarangam, 2013).

Fly ash contains a huge problem for disposal as it is a waste product itself (Kanchan et al., 2015). The present annual quantity of fly ash generated in India has increased from 98.57 million ton during 2004-05 to 184.14 million ton during 2014-15, a growth of about $90 \%$ (CEA, 2015). During the year 2014-15, about $42.26 \%$ of total fly ash generated was utilized in cement sector followed by $13 \%$ in mine filling, $11.72 \%$ in 
making bricks and tiles, $10.77 \%$ in reclamation of low lying areas, $9.56 \%$ in ash dyke raising, $3.32 \%$ in roads and embankments, $1.93 \%$ in agriculture, $0.74 \%$ in concrete, $0.01 \%$ in hydro power sector and $6.70 \%$ in others etc. (CEA, 2015).

The present study involves the evaluation of effect of fly ash on biochemical parameters of crop plants growing nearby Parichha Thermal Power Plant, Jhansi.

\section{Materials and Methods}

\section{Collection of samples}

Fresh leaves of wheat, maize, gram and pea from mature plants were collected from five different sites around Parichha Thermal Power Plant, Jhansi. Five replicate of each sample was collected from each site to minimize the sampling error. Samples were collected in polyethylene bags, labeled accordingly and brought to the laboratory for the biochemical analysis. The study was done for consecutively three years i.e. 20102013.

\section{Biochemical study}

Total chlorophyll and carotenoid content were estimated by Arnon, 1949. The amount of protein was estimated by the method of Lowry et al., 1951.

\section{Results and Discussion}

The results obtained for all biochemical parameters in various plants during 20102013 are presented in table 1, 2 and 3 respectively.

\section{Chlorophyll}

Chlorophylls are essential components for photosynthesis and occur in chloroplast as green pigments in all photosynthetic plant tissues (Rao, 2015). The chlorophyll contents were ranged between 1.10 to 1.59 (2010-11), 1.12 to $1.88(2011-12), 1.24$ to 1.95 (2012-13) in wheat, 0.95 to 1.75 (2010$11), 1.13$ to 1.75 (2011-12), 1.29 to 1.95 (2012-13) in maize. Similar pattern was also observed in gram and pea. It is noticeable that chlorophyll content is increasing regularly. It might be due to the presence of high concentration of nitrogen, potassium, magnesium and phosphorous in fly ash which is regularly depositing in the soil nearby Parichha Thermal Power plant. Similar results were also reported in Coelus forskohlii and Andrographis paniculata (Sinha et al., 2013).

\section{Carotenoids}

Carotenoids are colourful organic pigments found in chloroplasts and chromoplasts of plants. These pigments may elevate the photosynthetic activity, which resulted in improved growth and yield of plant (Khan and Khan, 1996). The result shows the elevation of carotenoid content during 201011 and 2011-12 while it is declining during 2012-13 in all cereals. The carotenoid content is increasing due to presence of utilizable plant nutrients like sulphate, phosphorous, potassium, calcium, boron, magnesium, manganese etc. in fly ash. Increasing trend of carotenoid in maize is also recorded by Agarwal, 2005.

\section{Protein}

Protein concentration was recorded $13.2 \%$ to $18.9 \%$ in wheat, $20.5 \%$ to $25.6 \%$ in maize, $12.2 \%$ to $21.5 \%$ in gram and $18.2 \%$ to $19.8 \%$ in pea during $2010-11$. The protein concentration was increased during 2011-12. It was recorded $19.4 \%$ to $22.2 \%$ in wheat, $22.6 \%$ to $27.5 \%$ in maize, $17.2 \%$ to $19.5 \%$ in gram and $21.9 \%$ to $24.8 \%$ in pea. It was increased again in 2012-13 and found $15.5 \%$ to $19.3 \%$ in wheat, $21.2 \%$ to $28.6 \%$ in maize, $24.2 \%$ to $29.9 \%$ in gram and $19.2 \%$ 
to $29.7 \%$ in pea. Protein concentration showed a remarkable increase consistently, which suggests synthesis of some new proteins which helps the affected plants to combat the stress induced by fly ash.

Table.1 Different biochemical parameters in various crops around Parichha Thermal Power Plant during 2010-2011

\begin{tabular}{|l|c|c|c|c|c|c|c|c|c|c|c|c|c|c|c|}
\hline \multirow{2}{*}{ Plant } & \multicolumn{4}{|c|}{$\begin{array}{c}\text { Total chlorophyll } \\
\text { (mg/g of FW) }\end{array}$} & \multicolumn{4}{c|}{$\begin{array}{c}\text { Carotenoids } \\
\text { (mg/g of FW) }\end{array}$} & \multicolumn{4}{c|}{ Protein } \\
(\%)
\end{tabular}

Table.2 Different biochemical parameters in various crops around Parichha Thermal Power Plant during 2011- 12

\begin{tabular}{|c|c|c|c|c|c|c|c|c|c|c|c|c|c|c|c|}
\hline \multirow{2}{*}{ Plant } & \multicolumn{5}{|c|}{$\begin{array}{c}\text { Total chlorophyll } \\
\text { (mg/g of FW) }\end{array}$} & \multicolumn{5}{|c|}{$\begin{array}{c}\text { Carotenoids } \\
\text { (mg/g of FW) }\end{array}$} & \multicolumn{5}{|c|}{$\begin{array}{l}\text { Protein } \\
(\%)\end{array}$} \\
\hline & $\mathrm{S} 1$ & $\mathrm{~S} 2$ & S3 & S4 & S5 & $\mathrm{S} 1$ & S2 & S3 & S4 & S5 & S1 & S2 & S3 & S4 & S5 \\
\hline Wheat & 1.12 & 1.22 & 1.75 & 1.62 & 1.88 & 0.21 & 0.22 & 0.45 & 0.27 & 0.56 & 19.4 & 19.9 & 21.5 & 20.3 & 22.2 \\
\hline Maize & 1.13 & 1.42 & 1.68 & 1.50 & 1.75 & 0.19 & 0.25 & 0.38 & 0.28 & 0.55 & 22.6 & 25.5 & 25.5 & 26.9 & 27.5 \\
\hline Gram & 2.20 & 2.25 & 2.69 & 2.56 & 2.85 & 0.26 & 0.35 & 0.35 & 0.35 & 0.55 & 17.2 & 18.2 & 18.9 & 18.5 & 19.5 \\
\hline Pea & 1.42 & 1.95 & 2.11 & 1.98 & 2.18 & 0.24 & 0.28 & 0.48 & 0.38 & 0.59 & 21.9 & 22.5 & 24.2 & 22.7 & 24.8 \\
\hline
\end{tabular}

Table.3 Different biochemical parameters in various crops around Parichha Thermal Power Plant during 2012-13

\begin{tabular}{|c|c|c|c|c|c|c|c|c|c|c|c|c|c|c|c|}
\hline \multirow{2}{*}{ Plant } & \multicolumn{5}{|c|}{$\begin{array}{l}\text { Total chlorophyll } \\
\text { (mg/g of FW) }\end{array}$} & \multicolumn{5}{|c|}{$\begin{array}{c}\text { Carotenoids } \\
\text { (mg/g of FW) }\end{array}$} & \multicolumn{5}{|c|}{$\begin{array}{l}\text { Protein } \\
(\%)\end{array}$} \\
\hline & S1 & $\mathrm{S} 2$ & S3 & $\mathrm{S} 4$ & S5 & $\mathrm{S} 1$ & $\mathrm{~S} 2$ & $\mathrm{~S} 3$ & S 4 & S5 & $\mathrm{S} 1$ & S2 & $\mathrm{S} 3$ & S4 & S5 \\
\hline Wheat & 1.24 & 1.25 & 1.76 & 1.84 & 1.95 & 0.24 & 0.25 & 0.27 & 0.33 & 0.35 & 15.5 & 15.6 & 17.8 & 18.5 & 19.3 \\
\hline Maize & 1.29 & 1.45 & 1.75 & 1.84 & 1.95 & 0.25 & 0.26 & 0.28 & 0.27 & 0.29 & 21.2 & 28.6 & 24.5 & 24.8 & 25.9 \\
\hline Gram & 1.22 & 1.44 & 1.85 & 2.25 & 2.55 & 0.30 & 0.31 & 0.32 & 0.35 & 0.39 & 24.2 & 26.8 & 28.8 & 29.2 & 29.9 \\
\hline Pea & 1.98 & 2.08 & 2.35 & 2.55 & 2.80 & 0.32 & 0.38 & 0.38 & 0.44 & 0.49 & 19.2 & 20.8 & 21.5 & 25.5 & 29.7 \\
\hline
\end{tabular}

The similar observations were also reported in Medicago sativa (Chakraborty, 2009), Brassica juncea (Gautam et al., 2012) and Caulerpa scalpelliformis (Sornalakshmi and Kumar, 2014). Soil metabolic activities, activities of amylase, invertase and protease, chlorophyll a and b, carotenoid and protein content are increases in fly ash amended soil (Bhandari, 2006; Bozkurt and Karacal, 2001; Rai et al., 2003).

In conclusion, the present study concluded that fly ash could be beneficial in improving 
plant growth and soil quality at a limited extent. But if it used in excess amount it could results vice versa. Utilization of fly ash in agriculture fields can also be one more strategy of fly ash management.

\section{Acknowledgement}

The authors are thankful to University Grants Commission, New Delhi, India for their financial assistance of this study. Authors are also thankful to Department of Biochemistry, Bundelkhand University, Jhansi to provide necessary facilities to complete this study.

\section{References}

Agarwal, S.K. 2005. Wealth from waste. A.P.H. Publishing Corporation, New Delhi. pp. 67-94.

Arnon, D.I. 1949. Copper enzymes in isolated chloroplast, polyphenol oxidase in Beta vulgaris. Plant Physiol., 1-15.

Bhandari, K. 2006. Studies on the effect of fly ash and plant hormones treated soil in the increased protein and amino acid content in the seeds ground nut. Asian J. Chem., 20: 15.

Bozkurt, M.A. and Karacal, I. 2001. Quantitative relationship between nutrient contents and oil quality of sunflower seed. J. Food \& Sci. Technol., 38(6), 635-638.

CEA. 2015. Report on fly ash generation at coal/lignite based thermal power stations and its utilization in the country for the year 2014-15. Central Electricity Authority, New Delhi.

Chakraborty, S., Solanki, R., Dave, J., Rana, S., Kumar, R.N. and Bhattacharya, T. 2009. Effect of airborne fly ash deposition on morphology and biochemcical parameters of Medicago sativa L. and Brassica juncea. Res. Environ. Life Sci., 2(1): 13-16.

Gautam, S., Singh, A., Singh, J. and Shikha. 2012. Effect of flyash amended soil on growth and yield of Indian mustard (Brassica juncea. Adv. Biores., 3(4), 39-45.

Kanchan, S., Kumar, V., Yadav, K.K., Gupta, N., Arya, S. and Sharma, S. 2015. Effect of fly ash disposal on ground water quality near Parichha Thermal Power Plant, Jhansi: a case study. Curr. World Environ., 10 (2), 572-580.

Khan, M.R. and W.M. Khan. 1996. The effect of fly ash on plant growth and yield of tomato. Environ. Pollu., 92(2): 105-111.

Lowry, O.H., Rosenbrough, N.H., Farr, A.L. and Randall, R.J. 1951. Protein measurements with Folin-phenol reagent. The J. Biol. Chem., 193: 265-275.

Mehra, A., Farago, M.E. and Banerjee, D.K. 2000. A study of Eichorrnia crassipes growing in the overbank and floodplains soils of the river Yamuna in Delhi, India. Environ. Monitoring and Assessment, 60(1), 25-45.

Murugan, S. and Vijayarangam, M. 2013. Effect of fly ash in agricultural field on soil properties and crop productivity- a review. Int. J. Engi. Res. Technol., 2(12), 54-60.

Rai, V.H., Gupta, D.K., Akhtar and Pal, A. 2003. Performance of seed germination and growth in victoria coal fly ash amended soil. J. Environ. Biol., 24(1): 9-15.

Rao, S.N. 2015. Effects of fly ash of on certain biochemical parameters of Coleus forskohlii. Int. J. Appl. Pure Sci. Agri., 1(12): 81-84.

Sharma, S., Kumar, V., Yadav, K.K., Gupta, N. and Verma, C. 2015. Long-term assessment of fly ash disposal in 
physic-chemical properties of soil. Int. J. Curr. Res. Biosci. Plant Biol., 2(8); 105-110.

Sinha, D., Sharma, S. and Dwivedi, M.K. 2013. The impact of fly ash on photosynthetic activity and medicinal property of plants. Int. J. Curr. Microbiol. Appl. Sci., 2(8): 382-388. Sornalakshmi, V. and Kumar, V. 2014. Effect of fly ash on the growth and biochemicals of some seaweed. Biosci. Discovery, 5(1): 1-5.

\section{How to cite this article:}

Sudarshana Sharma, Vinit Kumar, Krishna Kumar Yadav, Neha Gupta, Sanjay Kumar Vishwakarma. 2016. Effect of Fly Ash Deposition on Biochemical Parameters of Different Crop Plants around Parichcha Thermal Power Plant, Jhansi. Int.J.Curr.Microbiol.App.Sci. 5(8): 873-877. doi: http://dx.doi.org/10.20546/ijcmas.2016.508.098 